\title{
Clinical Approach to Renal Artery Thromboembolism
}

\author{
Renal tromboemboliye Klinik Yaklaşım
}

\author{
İbrahim Kartal ${ }^{1}$, Okan Alkış ${ }^{1}$, Mustafa Baturay Çetinkaya ${ }^{1}$, Sinan Çelen ${ }^{2}$, Bekir Aras ${ }^{1}$
}

\begin{abstract}
Aim: We aimed to reveal the clinical, laboratory, radiological findings of infarction in the renal artery and its branches due to thrombosis, its effects on renal functions and the measures to be taken.

Methods: The study sample included 8 patients who were admitted to the emergency department of Kutahya University of Health Sciences Evliya Celebi Training and Research Hospital between 2018-2020, and who were hospitalized with the diagnosis of acute renal infarction. Patients were retrospectively analyzed with clinical findings, CT angiography-abdomen, clinical observations, prognosis and complications.

Results: Of the patients, 5 were male and 3 were female. The mean age was 55.13 (29-69) years. One patient presented with bilateral renal infarction, while 7 had unilateral renal infarction. The etiology of the patients was idiopathic in 2, atrial fibrilation (AF) in 3 patients, and atherosclerosis in 3 patient. The mean serum creatinine of $1.24(0.7-3.2) \mathrm{mg} / \mathrm{dl}$ and the mean blood leukocyte level of 16925 (11000-26000) mcL were determined. The mean length of hospital stay was 4.6 (3-7) days. Anticoagulant therapy was initiated in all patients for risk of recurrent renal infarction and thromboembolism.

Conclusion: We revealed that renal infarction, rarely seen in urology practice, has nonspecific clinical findings; therefore, it should be kept in mind in differential diagnosis for patients presenting with sudden-onset oblique or abdominal pain, and that diagnosis can be made using contrast-enhanced CT. We determined that AF and valvular heart diseases which cause atherosclerosis and cardiac thrombosis play an important role in the etiology.
\end{abstract}

Keywords: abdominal pain; computed tomography angiography; infarction; renal artery; thromboembolism
Amaç: Çalışmamızda renal arter ve dallarında izlenen trombüse bağlı infarktın; klinik, laboratuar, radyolojik bulgularını ve renal fonksiyonlara etkisi ile takibinde alınması gereken önlemlerin ortaya konulması amaçlandı. Gereç ve Yöntem: Çalışmamıza 2018-2020 arasında Kütahya SBÜ Evliya Çelebi Eğitim ve Araştırma Hastanesi acil servisine başvuran ve akut renal infarkt tanısı konularak yatırılan 8 hasta dahil edildi. Hastalar retrospektif olarak incelenerek klinik bulguları, anjio batın tomografileri, klinik gözlemleri, renal fonksiyonlarda görülen değișimleri, takiplerinde gelișen komplikasyon ve prognozları değerlendirildi.

Bulgular: 8 hastanın 5'i erkek, 3'ü kadın idi. Yaş ortalaması 55,13 (29-69) yıl olarak saptandı. Bir hastada bilateral, 7 hastada tek taraflı renal infarkt alanı izlendi. Hastaların etiyolojisinde 2 hasta idiyopatik, 3 hastada atriyal fibrilasyon, 3 hastada ateroskleroz vardı. Serum kreatinin ortalaması 1.24 (0,7-3,2) saptandı. Kan lökosit ortalaması 16925 (11000-26000) olarak tespit edildi. Hastaların ortalama hastane yatış süresi 4.6 gün (3-7) idi. Tüm hastalara tekrarlayan renal infarkt ve tromboemboli riski için antikoagülan tedavi başlandı.

Sonuç: Çalışmamızda üroloji pratiğinde nadir olarak görülen renal infarktın klinik bulgularının nonspesifik olup bu nedenle ani başlayan yan veya karın ağrısı kliniği ile başvuran hastalarda ayırıcı tanıda mutlaka akılda tutulması gerektiği ve kontrastlı tomografi ile tanı konulabileceğini ortaya koyduk. Etiyolojide ateroskleroz ve kardiyak trombüse neden olan AF, kapak hastalıklarının önemli rol oynadığını belirledik.

Anahtar kelimeler: karın ağrısı; anjio batın tomografi; infarct, renal arter tromboemboli
${ }^{1}$ Kutahya University of Health Sciences, Faculty of Medicine, Department of Urology, Kütahya, Turkey.

${ }^{2}$ Pamukkale University, Faculty of Medicine, Department of Urology, Denizli, Turkey.

(iD)

IK: $0000-0002-2313-3522$

OA: 0000-0001-6116-958

MBC. 0000-0001-5184-4164

SC:: $0000-0003-4309-2323$

BA: 0000-0002-7020-8830

Ethics Committee Approval: The study was approved by Kutahya University of Health Sciences ethical authority. (Project No: 2020/04-10, 25.02.2020)

Etik Kurul Onayı: Calıșma Kütahya sağlık Bilimleri Üniversitesi etik kurulu tarafından onaylanmıştır. (Proje No: 2020/04-10, 25.02.2020)

Conflict of Interest: No conflict of interest was declared by the authors.

Çıkar Çatışması: Yazarlar çıkar çatışması bildirmemișlerdir

Financial Disclosure: The authors declared that this study has received no financial support. Finansal Destek: Yazarlar bu çalışma için finansal destek almadıklarını beyan etmişlerdir.

Geliș Tarihi / Received: 01.07.2020

Kabul Tarihi / Accepted: 14.08.2020

Yayın Tarihi / Published: 31.08.2020

Sorumlu yazar / Corresponding author:

İbrahim Kartal

Adres/Address: Kütahya Health Science University, Faculty of Medicine, Department of Urology, 43000, Kütahya, Turkey.

e-posta: igk84@hotmail.com

Tel/Phone: +905556298424

Copyright (C) ACEM 


\section{Introduction}

Renal infarction (RI) is a rare $(0.004-0.007 \%)$ disease with high morbidity [1, 2]. The renal artery divides into segmental arteries in the kidney after originating from the aorta. Obstruction of the renal artery or the segmental arteries with thrombosis may lead to infarction in the kidney, which is an endartery organ. Renal infarction is mostly seen in older ages, but it can be seen at any age. The etiology of RI due to thromboembolism includes hypercoagulation, atrial fibrillation, valvular heart diseases and atherosclerosis [3, 4]. Since it has no pathognomonic clinical finding, diagnosis can be difficult. Sudden-onset of oblique pain, nausea, vomiting and fever may be observed. It is often confused with renal colic. In cases with no stone detection on examination and imaging, RI is easily diagnosed with appearance of hypodense infarct areas on contrast-enhanced computed tomography (CT). Renal dysfunctions may be seen depending on the size of the infarction. In treatment, angiographic thrombolysis or embolectomy is not recommended for segmental artery occlusions. In the current study, our aim was to reveal the clinical and radiological findings of acute segmental RI and its effect on renal functions.

\section{Material and methods}

After obtaining ethical approval (no. 2020/04-10 dated 25.02.2020) from the non-interventional ethics committee of Kutahya University of Health Sciences, we included 8 patients who were followed up with the diagnosis of acute RI in our clinic between 2018 and December 2020. The files of the patients were examined, and their complaints, clinical findings, comorbidities, serum creatinine and leukocyte values and all contrast-enhanced abdominal tomography images were recorded. The treatments and examinations were noted. In the follow-up, the patients' prognosis and the problems encountered were recorded. The data were analyzed using the SPSS (Statistical Package for Social Sciences) for Windows 22.0. In the data analysis, descriptive statistical methods (frequency, percentage, mean, standard deviation) were used. The results were evaluated at $95 \%$ confidence interval and $5 \%$ significance level.

\section{Results}

Of the patients, 5 were male and 3 were female. The mean age was 55.13 (29-69) years (Table 1). All patients were admitted to the emergency room with the complaints of severe oblique and abdominal pain. Contrast-enhanced CT angiography revealed that 4 patients had RI on the right side, 3 had RI on the left side and 1 patient had bilateral RI (Figure 1). The infarction sizes varied between $4-10 \mathrm{~cm}$. Renal functions prior to RI were observed to be normal. Interventional radiology was consulted for angiographic thrombolysis or embolectomy. However, no intervention was considered due to the presence of segmental embolism in all patients. In the initial diagnosis, elevated serum creatinine levels were detected in one patient. The mean serum creatinine level was $1.24(0.7-3.2) \mathrm{mg} / \mathrm{dl}$. Leukocytosis was present in all patients. The mean blood leukocyte level was 16925 (11000-26000) mcL (Table 2). As etiological factors, 3 patients had atrial fibrillation (AF), while 3 had a history of coronary artery disease and peripheral arterial disease. The two remaining patients had no history of comorbidity. All patients were hospitalized, and initiated on hydration, parenteral antibiotics and analgesic treatment. All patients were relieved of their pain complaints after 1-3 days. The length of stay was 4.6 (3-7) days. The patient with bilateral RI persisted to present with elevated serum creatinine levels, which did not require renal replacement therapy. The 2 patients with no etiological factors

Table 1. Demographic and clinical data

\begin{tabular}{ll}
\hline Gender $\quad$ Male & 5 \\
$\quad$ Female & 3 \\
Age (mean)(min-max) & 55.13 (29-69) \\
Kidney with infarction & \\
Right & 4 \\
Left & 3 \\
Bilateral & 1 \\
Mean serum creatinine level , (min-max) mg/dl & $1.24(0.7-3.2)$ \\
Mean blood leukocyte level, (min-max) mcL & $16925(11000-26000)$ \\
Mean length of hospital stay, (min-max) days & $4.6(3-7)$
\end{tabular}

Figure 1: CT angiography images

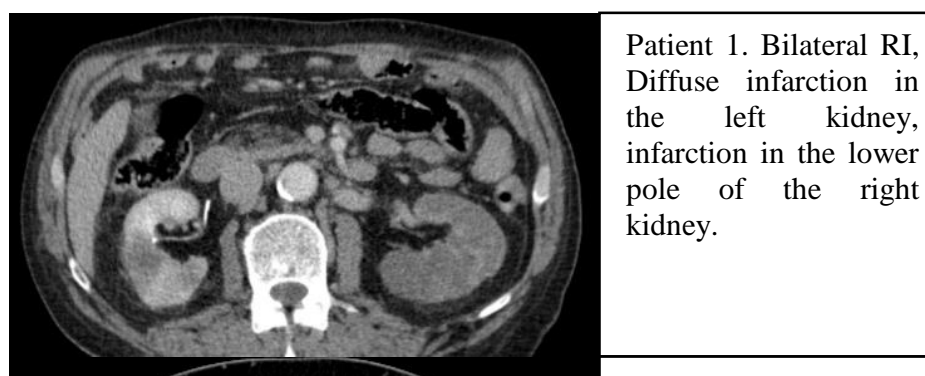

Patient 2. Infarction in the upper and middle poles of the right kidney.
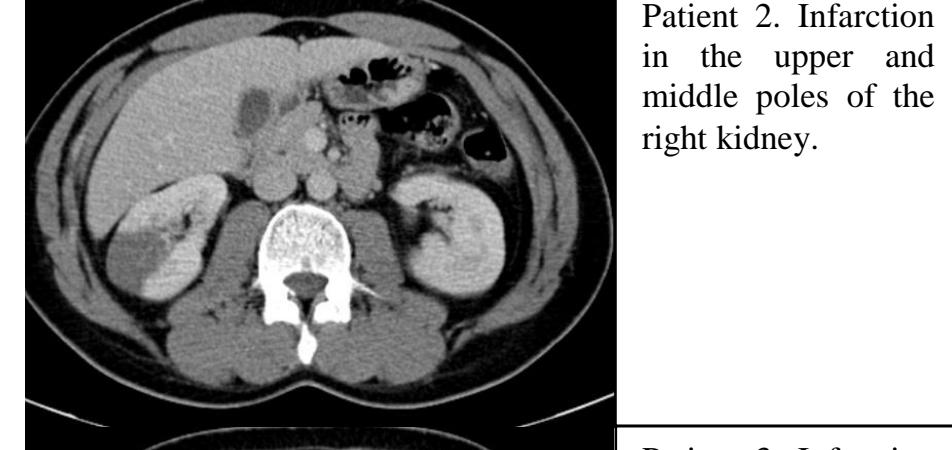

Patient 3. Infarction
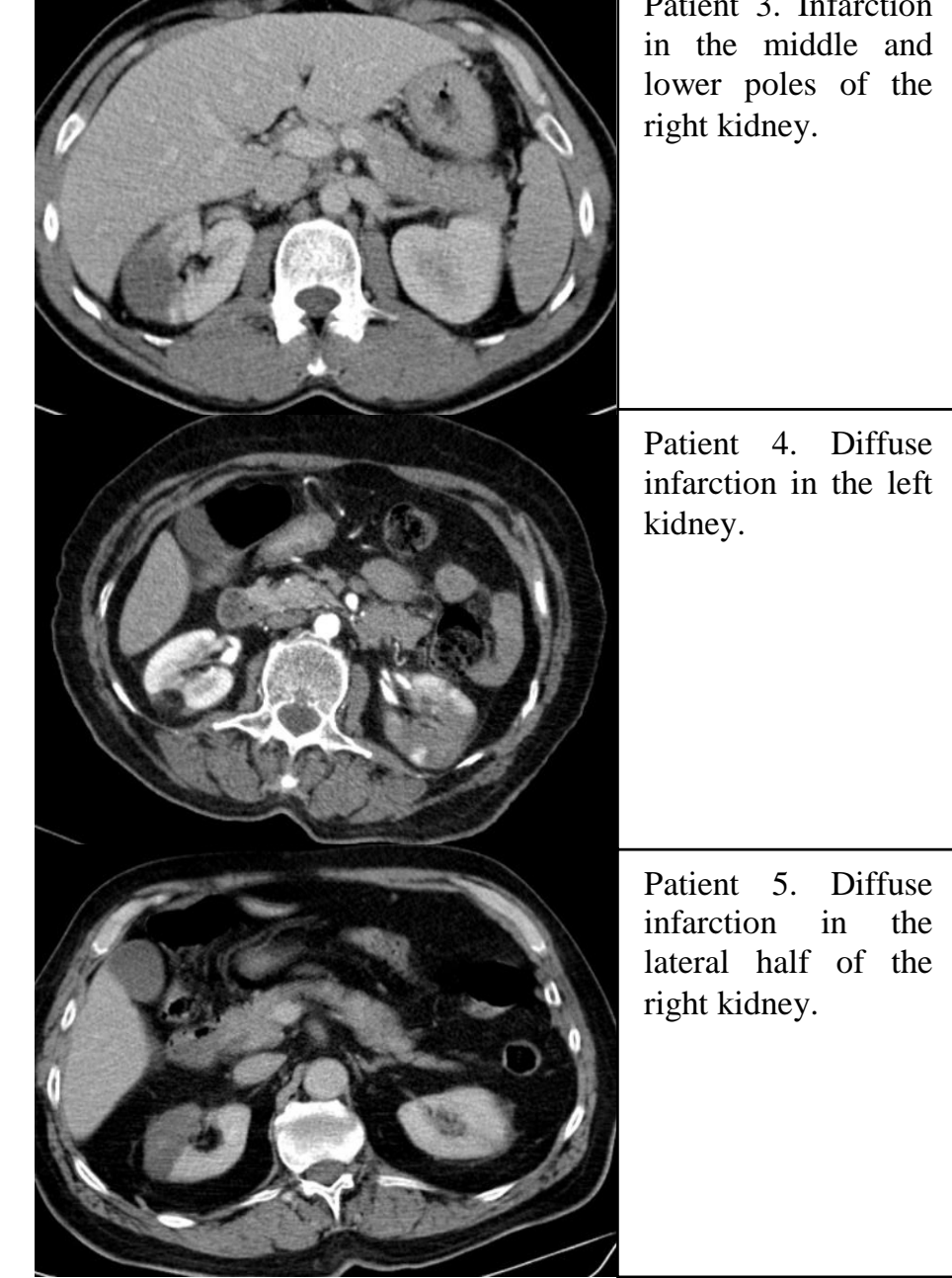
were examined in detail for hypercoagulopathy. However, no pathology was found. In the follow-up of one patient, pulmonary embolism developed with stroke secondary to cerebral embolism after 1 month on prophylaxis (Table 3 ).

Table 2. Demographic data and clinical and laboratory findings

\begin{tabular}{|c|c|c|c|c|c|c|}
\hline Patients & Gender & Age & $\begin{array}{l}\text { Affected } \\
\text { kidney }\end{array}$ & Localization & $\begin{array}{l}\text { S-Creatinine } \\
\mathrm{mg} / \mathrm{dl}\end{array}$ & $\begin{array}{l}\text { Leukocyte } \\
\mathrm{mcL}\end{array}$ \\
\hline 1 & Male & 63 & Bilateral & $\begin{array}{l}\text { Left: Diffuse } \\
\text { Right: Lower pole } \\
3 \mathrm{~cm}\end{array}$ & 3.2 & 19000 \\
\hline 2 & Female & 29 & Left & $\begin{array}{l}\text { Upper and middle pole } \\
4 \mathrm{~cm}\end{array}$ & 0.8 & 11000 \\
\hline 3 & Male & 43 & Right & $\begin{array}{l}\text { Middle and lower pole } \\
6 \mathrm{~cm}\end{array}$ & 0.8 & 13500 \\
\hline 4 & Female & 57 & Left & Diffuse & 0.9 & 26000 \\
\hline 5 & Male & 69 & Right & Diffuse & 0.9 & 13900 \\
\hline 6 & Male & 58 & Right & $\begin{array}{l}\text { Upper and middle pole } \\
5 \mathrm{~cm}\end{array}$ & 0.8 & 18000 \\
\hline 7 & Female & 68 & Right & $\begin{array}{l}\text { Upper, middle and } \\
\text { lower pole } 9 \mathrm{~cm}\end{array}$ & 1.1 & 18000 \\
\hline 8 & Male & 54 & Left & $\begin{array}{l}\text { Middle and lower pole } \\
5 \mathrm{~cm}\end{array}$ & 1.0 & 16000 \\
\hline
\end{tabular}

Table 3. Etiology, comorbidities and prognosis

\begin{tabular}{|c|c|c|c|}
\hline Patients & Etiology & Comorbidities & Prognosis \\
\hline 1 & $\mathrm{AF}$ & $\begin{array}{l}\mathrm{AF} \text {, ischemic heart disease, } \\
\text { hypertension }\end{array}$ & $\begin{array}{l}\text { Pulmonary } \\
\text { embolism } \\
\text { and stroke after } 1 \\
\text { month }\end{array}$ \\
\hline 2 & Idiopathic & No & Healthy \\
\hline 3 & Idiopathic & No & Healthy \\
\hline 4 & Atherosclerosis & $\begin{array}{l}\text { Diabetes, ischemic heart disease, } \\
\text { hypertension }\end{array}$ & Healthy \\
\hline 5 & $\mathrm{AF}$ & $\begin{array}{l}\mathrm{AF} \text {, ischemic heart disease, } \\
\text { hypertension }\end{array}$ & Healthy \\
\hline 6 & $\mathrm{AF}$ & $\begin{array}{l}\mathrm{AF} \text {, ischemic heart disease, } \\
\text { hypertension }\end{array}$ & Healthy \\
\hline 7 & Atherosclerosis & $\begin{array}{l}\text { Diabetes, ischemic heart disease, } \\
\text { hypertension }\end{array}$ & Healthy \\
\hline 8 & Atherosclerosis & $\begin{array}{l}\text { Diabetes, ischemic heart disease, } \\
\text { hypertension }\end{array}$ & Healthy \\
\hline
\end{tabular}

\section{Discussion}

Renal infarction is a rare health condition that may lead to serious morbidity and mortality. The literature shows that patients admitted to the emergency room have an incidence rate of $0.003-0.013 \%$ [3-5]. We found that patients admitted to the emergency room in the city of Kutahya had an RI incidence rate of $0.003 \%$. The diagnosis of RI consists of nonspecific symptoms and laboratory findings such as abdominal pain, oblique pain, fever, nausea, vomiting, leukocytosis and high creatinine levels, and it can be quite difficult to diagnose [6]. Renal infarction patients considered to have renal colic, and in cases of no ureteral stone on non-enhanced abdominal CT, RI should be considered in the differential diagnosis. In these cases, CT should be repeated as contrast enhanced. Renal infarction can only be diagnosed by contrast-enhanced abdominal CT. On CT, the hypodense infarction separated from renal parenchyma by sharp borders is observed as an area with no blood supply [7].
While contrast-enhanced CT can show this hypodense infarction area, CT angiography is recommended to observe arterial anomalies and the embolism area [8].

The etiology of RI often includes pathologies such as AF, which causes cardiac thromosis, hypercoagulation and atherosclerosis, although it can also develop idiopathically [9, 10]. In the present study, similar to the literature, 3 patients were thought to have developed AF, 3 atherosclerosis and 2 idiopathic RI. In the follow-up of these patients, the risk of recurrent RI and thromboembolism in other organs is quite high [11]. For patients with etiological risk factors after RI, anticoagulant therapy is recommended. In the current study, anticoagulant therapy was initiated in 6 patients with $\mathrm{AF}$ and atherosclerosis. One patient with AF had cerebral embolism in addition to pulmonary embolism 1 month after RI, despite the anticoagulant therapy.

Renal dysfunction with high morbidity can also be seen after RI. Renal dysfunction is associated with the size of the infarction area $[12,13]$. Patients with renal dysfunction before RI, bilateral cases and unilateral global infarctions often present with impaired renal functions. In these patients, the contrast agent given during CT angiography is also a nephrotoxic agent. Contrast nephropathy can aggravate renal dysfunction in risky cases. In this study, one patient who developed bilateral RI developed kidney failure that did not require renal replacement therapy.

There is no curative treatment protocol after RI. Patients are recommended to receive anticoagulant therapy, hydration, antibiotherapy and symptomatic treatments such as analgesics and antiemetics. In cases of renal dysfunction, nephrotoxic medical agents should be avoided [14, 15]. In our study, all patients were hospitalized. Then, prophylactic antibiotherapy, hydration and symptomatic treatments were administered. No complication was observed in the follow-up, and the patients were discharged with no problems.

The main limitations of our study are its retrospective design, single-center nature, and limited number of patients. Despite that, our study can be a guide for prospective studies on RI.

\section{Conclusion}

Although rare, RI is an important disease that is difficult to diagnose, has no clear treatment, and can occasionally cause serious morbidity such as chronic renal failure. For patients with etiological risk factors such as AF and other pathologies that lead to cardiac thrombosis, atherosclerosis and hypercoagulation, anticoagulant therapy is the key to prevent the development of RI. In patients with RI, care should be taken along with preventive measures for renal dysfunction and recurrent thromboembolism.

\section{References}

1. Domanovits H, Paulis M, Nikfardjam M, Meron G, Kurkciyan I, Bankier AA, et al. Acute renal infarction. Clinical characteristics of 17 patients. Medicine (Baltimore). 1999;78(6):386-94. Epub 1999/11/27. doi: 10.1097/00005792-199911000-00004. PubMed PMID: 10575421

2. Korzets Z, Plotkin E, Bernheim J, Zissin R. The clinical spectrum of acute renal infarction. Isr Med Assoc J. 2002;4(10):781-4. Epub 2002/10/23. PubMed PMID: 12389340.

3. Nagasawa T, Matsuda K, Takeuchi Y, Fukami H, Sato H, Saito A, et al. A case series of acute renal infarction at a single center in Japan. Clin Exp Nephrol. 2016;20(3):411-5. Epub 2015/09/18 doi: 10.1007/s10157-015-1168-1. PubMed PMID: 26377692.

4. Mesiano P, Rollino C, Beltrame G, Ferro M, Quattrocchio G, Fenoglio R, et al. Acute renal infarction: a single center experience. J Nephrol. 2017;30(1):103-7. Epub 2016/01/09. doi: 10.1007/s40620-015-0259-0. PubMed PMID: 26743079.

5. Huang CC, Lo HC, Huang HH, Kao WF, Yen DH, Wang LM, et al. ED presentations of acute renal infarction. Am J Emerg Med. 
2007;25(2):164-9. Epub 2007/02/06.

doi:

10.1016/j.ajem.2006.06.010. PubMed PMID: 17276805.

6. Nandwani A, Pathania D, Jha PK, Kher V. Renal Artery

Thrombosis with Renal Infarction: A Rare Cause of Acute Abdomen. Indian J Nephrol. 2017;27(4):313-5. Epub 2017/08/02. doi: 10.4103/0971-4065.183581. PubMed PMID: 28761235; PubMed Central PMCID: PMCPMC5514829.

7. Suzer O, Shirkhoda A, Jafri SZ, Madrazo BL, Bis KG, Mastromatteo JF. CT features of renal infarction. Eur J Radiol. 2002;44(1):59-64. Epub 2002/09/28. doi: 10.1016/s0720048x(01)00476-4. PubMed PMID: 12350414.

8. Zhang ZG, Liu XM. [Clinical characteristics of patients with acute renal infarction: an analysis of 52 patients in a single center]. Beijing Da Xue Xue Bao Yi Xue Ban. 2019;51(5):863-9. Epub 2019/10/19. PubMed PMID: 31624390.

9. Hazanov N, Somin M, Attali M, Beilinson N, Thaler M, Mouallem M, et al. Acute renal embolism. Forty-four cases of renal infarction in patients with atrial fibrillation. Medicine (Baltimore). 2004;83(5):292-9. Epub 2004/09/03. doi: 10.1097/01.md.0000141097.08000.99. PubMed PMID: 15342973.

10. Rhee H, Song SH, Won Lee D, Lee SB, Kwak IS, Seong EY. The significance of clinical features in the prognosis of acute renal infarction: single center experience. Clin Exp Nephrol. 2012;16(4):611-6. Epub 2012/02/22. doi: 10.1007/s10157-0120605-7. PubMed PMID: 22350465.

11. Ongun S, Bozkurt O, Demir O, Cimen S, Aslan G. Midterm renal functions following acute renal infarction. Kaohsiung J Med Sci. 2015;31(10):529-33. Epub 2015/11/02. doi: 10.1016/j.kjms.2015.07.005. PubMed PMID: 26520692.

12. Bae EJ, Hwang K, Jang HN, Kim MJ, Jeon DH, Kim HJ, et al. A retrospective study of short- and long-term effects on renal function after acute renal infarction. Ren Fail. 2014;36(9):1385-9. Epub 2014/08/13. doi: 10.3109/0886022X.2014.947514. PubMed PMID: 25112371

13. Kagaya S, Yoshie O, Fukami H, Sato H, Saito A, Takeuchi Y, et al. Renal infarct volume and renal function decline in acute and chronic phases. Clin Exp Nephrol. 2017;21(6):1030-4. Epub 2017/03/12. doi: 10.1007/s10157-017-1399-4. PubMed PMID: 28283850 .

14. Eren N, Gungor O, Kocyigit I, Guzel FB, Erken E, Altunoren O, et al. Acute renal infarction in Turkey: a review of 121 cases. Int Urol Nephrol. 2018;50(11):2067-72. Epub 2018/09/27. doi: 10.1007/s11255-018-1979-6. PubMed PMID: 30251011.

15. Tascon GC, Chiriboga DES, Ramos RL, Diaz Diaz D, Ruiz CR, Procaccini FL, et al. [Renal infarction in a patient with active COVID -19 infection]. Nefrologia. 2020. Epub 2020/05/16. doi: 10.1016/j.nefro.2020.04.008. PubMed PMID: 32410764; PubMed Central PMCID: PMCPMC7221395. 